\title{
KEPERCAYAAN SEBAGAI MEDIASI HUBUNGAN CORPORATE IMAGE TERHADAP LOYALITAS PELANGGAN MOBIL LOW MPV
}

\author{
Iva Nurdiana Nurfarida \\ Fakultas Ekonomika dan Bisnis Universitas Kanjuruhan Malang \\ Jl. S. Supriyadi No. 48 Malang \\ Eris Dianawati \\ Fakultas Ekonomika dan Bisnis Universitas Kanjuruhan Malang \\ Jl. S. Supriyadi No. 48 Malang
}

\begin{abstract}
The program's cost environmentally friendly cars or Low MPV (LCGC) issued by the Indonesian government to bring the impact of the availability of consumer choices Indonesia to buy a car at a bargain price. The challenge is whether consumers have confidence that the car MPV although low cost but still quality. Nearly all car manufacturers to get the car with this type so that competition in the automotive business has become very competitive. This study aims to determine causality corporate image to build customer trust and customer loyalty Low MPV car. The study was conducted on customers of Toyota cars, with the number of respondents 150, using accidental sampling and technique using path analysis. The results that the corporate image has a direct influence on the increase in customer loyalty, as well as striving indirectly through increased customer confidence LCGC Toyota. Manufacturer Toyota has the advantage of the corporate image of the customer against Toyota is high, so the products LCGC Toyota produced can be accepted by consumers for consumers / customers have a loyalty to Toyota, meaning that the high corporate image car customers LCGC Toyota lead to customer loyalty. Another result of this study that the corporate image is also able to increase customer confidence LCGC Toyota subsequent impact on improving customer loyalty, meaning that belief becomes a mediation of the causal relationship of corporate image on customer loyalty.
\end{abstract}

Keywords: Customer Trust, Corporate Image, Loyalty

DOI : http://dx.doi.org/10.21067/jem.v12i3.1442

Diterima: Agustus 2016; Direvisi: Agustus, 2016; Diterima : Oktober 2016

\section{PENDAHULUAN}

Indonesia merupakan negara berkembang dengan jumlah penduduk besar merupakan pasar potensial bagi produsen industri otomotif dalam memasarkan produknya. Saat ini tercatat produsen besar seperti seperti Toyota, Daihatsu, Honda, Suzuki, Mitsubishi, Nissan sudah mempunyai pasar di Indonesia.

* Corresponding Author.

ivanurdiana@unikama.ac.id
Salah satu jenis kendaraan yang diproduksi adalah mobil keluarga atau dikenal dengan Multi Purpose Vehicle (MPV) menjadi kendaraan pilihan yang masih menjadi primadona di Indonesia. Segmen Low MPV merupakan segmen paling ketat diperebutkan oleh industri mobil di Indonesia. Hal tersebut terlihat dari penjualan 2013, dimana segmen ini menyumbang 379.205 unit atau $31 \%$ dari total penjualan mobil. Ramainya segmen pasar Low MPV mulai terjadi pada 2003, ketika Toyota dan 
Daihatsu berkolaborasi melahirkan mobil dengan karakteristik dapat memuat banyak orang, 7 - 8 orang, namun dengan harga yang relatif terjangkau. Salah satu produk Low MPV produksi Toyota adalah Avanza yang hingga saat ini tetap menjadi pilihan keluarga Indonesia dalam membeli kendaraan, walaupun sudah banyak kendaraan sejenis yang diproduksi oleh perusahaan lain. Selama tahun 2013 sampai Juni 2014, Toyota Avanza berhasil menguasai pangsa pasar Low MPV sebesar $43 \%$ atau menguasai pangsa pasar $14,1 \%$ dari total penjualan di semua segmen pasar.

Tingkat persaingan industri otomotif di Indonesia masih berlanjut setelah pemerintah mencanangkan program mobil murah ramah lingkungan atau Low Cost and Green Car (LCGC). Kebijakan ini membuat produsen otomotif mencari alternatif untuk menghadirkan mobil dengan harga terjangkau untuk semua segmen. Toyota dan Daihatsu menghadirkan Agya dan Ayla, sementara Suzuki mengeluarkan Karimun Wagon, Honda mengeluarkan Brio Satya, terbaru tahun 2015 Datsun juga mengeluarkan produk LGCC. Selain kompetisi yang semakin sengit, industri otomotif juga dihadapkan dengan beberapa faktor eksternal, seperti transisi pemerintahan, fluktuasi rupiah, dan kenaikan harga premium (Saputra \& Herdi, 2015).

Produsen otomotif harus melakukan peran strategi baik strategi harga, kualitas produk, distribusi, promosi, dan layanan pelanggan, untuk bisa bertahan dalam persaingan. Guna memenangkan persaingan, kepuasan pelanggan belumlah cukup tanpa dibarengi loyalitas. Selain beberapa strategi diatas yang perlu diperhatikan perusahaan adalah menjaga brand image, karena merek yang positif akan mampu menaikkan kinerja perusahaan. Sebaliknya merek yang buruk akan menyebabkan perusahaan kehilangan pelanggannya. Selain brand image yang tidak kalah penting adalah corporate image, sebagai sebuah potret perusahaan meliputi aspek tingkat keyakinan, ide, dan gambaran pelanggan terhadap perusahaan (Kotler, 1993). Melihat keterkaitan antara corporate image dan keyakinan/ kepercayaan pelanggan dalam menciptakan loyalitas pelanggan maka perlu diteliti keterkaitan antara corporate image dengan kepercayaan pelanggan dan dampaknya terhadap loyalitas pelanggan. Oleh karena itu, kepuasan pelanggan harus dibarengi dengan loyalitas pelanggan (Tjiptono, 2006). Kualitas layanan mempengaruhi kepuasan, kepercayaan, dan nilai-nilai pelanggan yang selanjutnya berpengaruh terhadap loyalitas pelanggan (Shpetim, 2012; Dornas et al, 2014; Kassim \& Abdullah, 2010; Chodzaza \& Gombachika, 2013; Vuuren et al, 2012). Artikel ini akan menjawab beberapa pertanyaan tentang 1) Bagaimana peran corporate image dalam membangun kepercayaan pelanggan; 2) bagaimana peran corporate image dalam menciptakan loyalitas pelanggan; 3) bagaimana peran kepercayaan pelanggan dalam menciptakan loyalitas pelanggan.

\section{TINJAUAN PUSTAKA \\ Corporate Image}

Corporate image atau citra perusahaan yang baik akan memberikan dorongan kepada konsumen untuk menjalin ikatan yang kuat dengan perusahaan. Selanjutnya ikatan tersebut memungkinkan perusahaan untuk lebih memahami secara seksama keinginan serta kebutuhan konsumen, sehingga dapat memenuhi keinginan dan kebutuhan konsumen (Tjiptono, 2000)

Corporate image adalah kesan-kesan yang muncul dalam pemikiran seseorang ketika mereka mendengar nama dari sebuah hotel, tempat, restoran, atau institusi bisnis lainnya. Corporate image menjelaskan hasil keseluruhan dari proses dimana pelanggan membandingkan dan beragam atribut perusahaan ( $\mathrm{Kim}$ et al, 2012). Corporate image atau citra perusahaan yang baik akan memberikan dorongan kepada konsumen untuk menjalin ikatan yang kuat dengan perusahaan. Menurut Walter dalam Lin \& Lu (2010) corporate image terdiri dari tiga yaitu insitutional image, functional image, dan comodity image. Flavian et al (2005) corporate image disusun dari lima dimensi yaitu akses terhadap layanan, layanan yang ditawarkan perusahaan, kontrak pribadi, reputasi dan keamanan.

Corporate image memiliki hubungan yang positif dengan loyalitas pelanggan (Johnson et al, 2001). Hasil penelitian Tu et al (2012) menyatakan bahwa corporate image memiliki pengaruh yang signifikan terhadap kepuasan dan loyalitas pelanggan. Wu (2011) 
juga menyatakan bahwa corporate image adalah sebagai antesenden penting dari kepuasan dan loyalitas pelanggan.

\section{Kepercayaan (Trust)}

Kepercayaan (trust) menurut Muawanah (2010) adalah kesediaan untuk bertindak berdasarkan keyakinan tentang motif pihak lain dan tingkat resiko yang terlibat dengan tindakan. Sultan et al (2002) memberikan sintesa menarik tentang trust dengan menunjukkan bahwa trust telah menjadi bagian dari semua hubungan. Trust menjadi penting dalam transaksi bisnis antara kedua belah pihak baik itu dalam bentuk $\mathrm{B} 2 \mathrm{~B}$ (business to business) maupun $\mathrm{B} 2 \mathrm{C}$ (business to customer), akan terjadi apabila masing-masing dilandasi oleh kepercayaan. Dalam kerangka hubungan B2C, kepercayaan terbentuk karena pelanggan memiliki harapan tertentu yang terukur secara ekonomi yang mendorongnya melakukan transaksi bisnis dengan perusahaan. Trust mempresentasikan tingkat kepercayaan konsumen terhadap keandalan dan integritas perusahaan. Mayer et al (1995) menyatakan kepercayaan terdiri dari kemampuan profesional, good will, dan integritas.

Kepercayaan merek memiliki pengaruh yang signifikan terhadap loyalitas merek (Rizan dan Saidani, 2012). Lehu (2001) menyatakan citra merupakan salah satu elemen yang memungkinkan pembangunan sebuah hubungan kepercayaan yang tulus antara kepuasan total dan loyalitas pelanggan. Hasil penelitian Vuuren et al (2012) menyatakan bahwa customer satisfaction, trust dan commitment sebagai variabel yang berpengaruh terhadap consumer loyalty. Demikian pula penelitian Nguyen (2013) bahwa trust berperan dalam menciptakan pelanggan, bahwa turst memiliki peran mediasi dalam corporate image terhadap peningkatan loyalitas pelanggan.

Yoon (2002) menyatakan variabel yang mempengaruhi kepercayaan adalah corporate image. Didukung pula penelitian Lin dan $\mathrm{Lu}$ (2010) bahwa corporate image memiliki pengaruh positif dan signifikan terhadap kepercayaan pelanggan, dan merupakan komoditas penting untuk menciptakan kepercayaan.

\section{Loyalitas Pelanggan}

Loyalitas pelanggan adalah komitmen pelanggan terhadap suatu merek atau pemasok berdasarkan sikap yang positif dan tercermin dalam pembelian ulang yang konsisten (Sheth \& Mittal, 2004). Terciptanya loyalitas pelanggan dapat memberikan beberapa manfaat, diantaranya 1) sensitivitas konsumen terhadap harga menjadi rendah, 2) penghematan biaya untuk mendapatkan pelanggan baru, dan 3) meningkatkan profitabilitas perusahaan, 5) bisa mengarahkan pelanggan, 6) mengurangi dampak keluhan pelanggan, 7) kesadaran yang besar terhadap merek (Rowley, 2006; Duffy, 2003). Kotler (2000) menyatakan "the long term success of the a particular brand is not based on the number of consumer who purchase it only once, but on the number who become repeat purchase". Pendapat tersebut dapat diartikan bahwa konsumen yang loyal tidak diukur dari berapa banyak dia membeli, tapi dari berapa sering dia melakukan pembelian ulang, termasuk disini merekonmendasikan orang lain untuk membeli. Adapun indikator dari loyalitas pelanggan menurut Kotler \& Keller (2006) adalah:

1. Repeat Purchase (kesetiaan terhadap pembelian produk)

2. Retention (tahan terhadap pengaruh yang negatif mengenai perusahaan)

3. Referalls (mereferensikan secara total esistensi perusahaan)

\section{METODE}

Penelitian ini dilakukan untuk menganalisis kepercayaan sebagai mediasi dari corporate image dalam membangun loyalitas pelanggan mobil low MPV di Malang. Kepercayaan berfungsi sebagai variabel mediasi hubungan corporate image dengan loyalitas pelanggan. Jadi penelitian ini ingin menjelaskan keterkaitan hubungan kausal langsung dan tidak langsung antar variabel, oleh karena itu penelitian ini termasuk dalam kategori penelitian eksplanatori (explanatory research). Populasi penelitian adalah pelanggan merek mobil low MPV Toyota di Auto 2000 Malang. Jumlah sampel ditetapkan berdasarkan kriteria yang dikemukakan Ghozali (2005) bahwa jumlah sampel bisa diambil 5 - 10 kali jumlah indikator. Indikator dalam penelitian ini adalah 
10, apabila ditetapkan 10 kali jumlah indikator maka sampel minimal adalah 100 pelanggan, namun untuk menjamin representatif populasi maka dalam penelitian ini sampel ditetapkan 150 pelanggan. Teknik pengambilan sampel menggunakan metode Accidental Sampling

Variabel dalam penelitian ini adalah corporate image sebagai variabel eksogen serta kepercayaan dan loyalitas pelanggan sebagai variabel endogen. Pengumpulan data dalam penelitian ini menggunakan kuesioner yang disusun dalam bentuk Skala Likert 5 point, skor 5 untuk tanggapan paling positif, sedangkan skor 1 untuk tanggapan paling negatif. Adapun operasional variabel yang digunakan untuk masing-masing variabel adalah corporate image disusun dari lima dimensi yaitu akses terhadap layanan, layanan yang ditawarkan perusahaan, kontrak pribadi, reputasi dan keamanan; kepercayaan (trust) menggunakan kredibilitas dan kebaikan. Sedangkan loyalitas pelanggan menggunakan repeat purchase, retention dan referalls.

Analisis data yang digunakan adalah Analisis Jalur (Path Analysis). Analisis Jalur merupakan pengembangan dari Analisis Regresi, dilakukan estimasi besarnya hubungan kausal antara sejumlah variabel dan hirarki kedudukan masing-masing variabel dalam serangkaian jalur-jalur hubungan kausal, baik hubungan langsung maupun tidak langsung.

Langkah-langkah analisis jalur (Path Analysis) adalah sebagai berikut:

1. Menggambar model teoritis berupa diagram jalur berdasarkan teori dan penelitian terdahulu yang relevan.

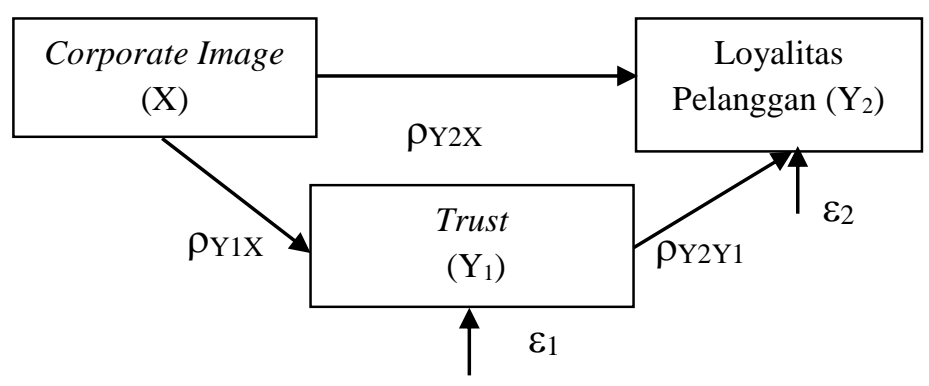

Gambar 1. Model Path Analysis

2. Berdasarkan model diagram jalur, dirumuskan persamaan model jalur hubungan kausal masing-masing variabel, yaitu sebagai berikut:

a. Hubungan kausal antara $\mathrm{X}, \mathrm{Y}_{1}$ dengan $\mathrm{Y}_{2}$

$\mathrm{Y}_{2}=\rho_{\mathrm{Y} 2 \mathrm{X}}+\rho_{\mathrm{Y} 2 \mathrm{Y} 1}+\varepsilon$

Keterangan:

$\rho_{\mathrm{Y} 2 \mathrm{X}}=$ Koefisien jalur $\mathrm{X}$ dengan $\mathrm{Y} 2$

$\rho_{\mathrm{Y} 2 \mathrm{Y} 1}=$ Koefisien jalur $\mathrm{Y} 1$ dengan $\mathrm{Y} 2$

$\varepsilon=$ Koefisien residual (Error)

b. Hubungan kausal antara $\mathrm{X}$ dengan $\mathrm{Y}_{1}$

$\mathrm{Y}_{1}=\rho_{\mathrm{Y} 1 \mathrm{X}}+\varepsilon$

Keterangan:

$\rho_{\mathrm{Y} 1 \mathrm{X}}=$ Koefisien jalur $\mathrm{X}$ dengan $\mathrm{Y} 1$

$\varepsilon \quad=$ Koefisien residual (Error)

3. Menafsirkan hasil pengolahan data dengan memperhatikan: a. Koefisien regresi standar (standardized coefficient) atau Beta yang berfungsi sebagai koefisien jalur $(\rho)$

b. Nilai $F_{\text {hitung }}$ sebagai uji model pada taraf signifikan $\alpha=5 \%$.

c. Nilai thitung untuk masing-masing Beta (koefisien jalur), yang menunjukkan signifikansi koefisien jalur yang bersangkutan.

4. Menghitung besarnya pengaruh langsung, pengaruh tidak langsung, dan pengaruh total. Pengaruh langsung dilihat dari besarnya koefisien jalur, sedangkan pengaruh tidak langsung dicari dengan cara mengalikan besarnya koefisien jalur standarisasi pada jalur yang terbentuk. 


\section{HASIL DAN PEMBAHASAN \\ Corporate Image}

Corporate Image dalam penelitian ini diukur melalui lima dimensi, yaitu: akses terhadap layanan, layanan yang ditawarkan perusahaan, kontrak pribadi, reputasi dan keamanan. Hasil deskripsi variabel corporate image menunjukkan bahwa para pelanggan mobil low MPV (LCGC) produksi Toyota memiliki citra yang baik terhadap Toyota, ditunjukkan oleh nilai rata-rata sebesar 3,86 artinya para pelanggan memilih mobil low MPV (LCGC) Toyota karena menganggap Toyota memiliki citra yang baik di mata pelanggan. Corporte image yang tinggi terhadap Toyota terutama didukung oleh dua hal yaitu pelanggan menganggap akses terhadap layanan Toyota sangat mudah dan faktor keamanan dari mobil low MPV (LCGC) Toyota. Selain kedua hal tersebut didukung pula oleh layanan yang ditawarkan menarik, adanya kontrak pribadi atau hubungan pelanggan dengan Toyota karena pernah memiliki mobil produksi Toyota, dan reputasi Toyota sebagai produsen mobil berkualitas.

Hasil ini mencerminkan bahwa mobil low MPV (LCGC) yang dihasilkan oleh Toyota mampu menembus pasar dan diterima oleh konsumen karena dukungan corporate image Toyota yang sudah baik di mata pelanggan. Tentunya kondisi ini menguntungkan bagi Toyota dalam menjual mobil low MPV (LCGC) dan bersaing dengan produsen low MPV (LCGC) merek lainnya.

\section{Kepercayaan}

Kepercayaan dalam penelitian ini diukur berdasarkan kredibilitas dan kebaikan/ kepentingan pelanggan. Hasilnya deskripsi variabel kepercayaan menunjukkan bahwa para pelanggan mobil low MPV (LCGC) produksi Toyota memiliki kepercayaan yang cukup tinggi terhadap mobil low MPV (LCGC) produksi Toyota, ditunjukkan oleh nilai rata-rata sebesar 3,57 artinya para pelanggan memilih mobil low MPV (LCGC) Toyota karena percaya Toyota menghasilkan produk mobil low MPV (LCGC) yang mampu mememuhi keinginan dan kebutuhan konsumen. Kepercayaan terhadap mobil low MPV (LCGC) Toyota didukung oleh kepercayaan bahwa Toyota akan menghasilkan produk yang kualitasnya baik, dan keyakinan bahwa Toyota akan selalu mengedepankan kepuasan pelanggan.

Hasil ini mencerminkan bahwa kesediaan pelanggan untuk membeli mobil low MPV (LCGC) karena adanya rasa percaya pelanggan yang tinggi terhadap produk keluarah Toyota khususnya mobil low MPV (LCGC). Tentunya kondisi ini menguntungkan bagi Toyota dalam menjual mobil low MPV (LCGC) dan bersaing dengan produsen low MPV (LCGC) merek lainnya.

\section{Loyalitas Pelanggan}

Loyalitas pelanggan diukur melalui komitmen pelanggan terhadap produk dan merek. Hasil deskripsi variabel kepercayaan menunjukkan bahwa para pelanggan mobil low MPV (LCGC) produksi Toyota memiliki loyalitas yang tinggi terhadap produksi mobil Toyota, ditunjukkan oleh nilai rata-rata sebesar 4,13 artinya para pelanggan memilih mobil low MPV (LCGC) Toyota karena mereka orang yang telah memiliki mobil Toyota sebelumnya dan sudah merasakan bagaimana produksi mobil Toyota. Loyalitas pelanggan mobil low MPV (LCGC) Toyota dicerminkan oleh kesetiaan untuk tetap membeli mobil Toyota, tidak terpengaruh oleh iklan merek lain yang berusaha menjelekkan produk Toyota, serta bersedia merekomendasikan kepada orang lain untuk membeli produk Toyota.

Hasil ini mencerminkan bahwa loyalitas pelanggan mobil low MPV (LCGC) karena adanya pengalaman menggunakan produk Toyota dan dianggap mobil Toyota mampu memenuhi keinginan dan kebutuhan pelanggan, mulailah tercipta loyalitas, bagaimanapun banyaknya merek-merek lain produksi selain Toyota mereka tidak terpengaruh, dan akhirnya pelanggan bersedia merekomendasikan kepada orang lain untuk membeli Toyota.

\section{Analisis Model 1}

Hasil analisis regresi antara corporate image $(\mathrm{X})$ dan kepercayaan $\left(\mathrm{Y}_{1}\right)$ terhadap loyalitas pelanggan $\left(\mathrm{Y}_{2}\right)$ disajikan pada tabel sebagai berikut: 
Tabel 1

Analisis Regresi Corporate Image (X) dan Kepercayaan $\left(\mathrm{Y}_{1}\right)$ terhadap Loyalitas Pelanggan $\left(\mathrm{Y}_{2}\right)$

\begin{tabular}{lcccc}
\hline \multicolumn{1}{c}{ Variabel Bebas } & $\mathrm{B}$ & $\mathrm{Beta}$ & $\mathrm{t}$ & Sig. \\
\hline Corporate Image $(\mathrm{X})$ & 0,475 & 0,467 & 6,327 & 0,000 \\
Kepercayaan $\left(\mathrm{Y}_{1}\right)$ & 0,314 & 0,401 & 5,432 & 0,000 \\
\hline Variabel Terikat & Loyalitas Pelanggan $\left(\mathrm{Y}_{2}\right)$ & & \\
$\mathrm{F}_{\text {hitung }}$ & 145,540 & & \\
Sig. & 0,000 & & \\
\hline \multicolumn{5}{l}{ Sumber: data primer diolah, 2016 }
\end{tabular}

Berdasarkan hasil analisis pada tabel di atas, maka dapat disusun persamaan jalur hubungan kausal antara corporate image (X) dan kepercayaan $\left(\mathrm{Y}_{1}\right)$ terhadap loyalitas pelanggan $\left(\mathrm{Y}_{2}\right)$ sebagai berikut: $\mathrm{Y}_{2}=0,467 \mathrm{X}+0,401 \mathrm{Y}_{1}$

Hasil analisis diperoleh nilai $\mathrm{F}_{\text {hitung }}=$ 145,540 dengan nilai signifikan 0,000 lebih kecil 0,05 dengan demikian model dapat menjelaskan hubungan kausal antara corporate image $(\mathrm{X})$ dan kepercayaan $\left(\mathrm{Y}_{1}\right)$ terhadap loyalitas pelanggan $\left(\mathrm{Y}_{2}\right)$.

Hasil Uji t untuk menguji signifikansi masing-masing variabel secara parsial dapat dijelaskan sebagai berikut: a. Jalur hubungan kausal $\mathrm{X}$ dengan $\mathrm{Y} 2$

Hasil analisis diperoleh nilai $\mathrm{t}_{\text {hitung }}=6,327$ dengan nilai signifikan $0,000<0,05$ dengan demikian dapat dinyatakan bahwa hubungan kausal antara corporate image dengan loyalitas pelanggan signifikan.

b. Jalur hubungan kausal Y1 dengan Y2

Hasil analisis diperoleh nilai $t_{\text {hitung }}=5,432$ dengan nilai signifikan $0,000<0,05$ dengan demikian dapat dinyatakan bahwa hubungan kausal antara kepercayaan dengan loyalitas pelanggan signifikan.

\section{Analisis Model 2}

Hasil regresi antara corporate image (X) terhadap kepercayaan $\left(\mathrm{Y}_{1}\right)$, sebagai berikut :

Tabel 2

Analisis Regresi Corporate Image (X) terhadap Kepercayaan ( $\left.\mathrm{Y}_{1}\right)$

\begin{tabular}{lcccc}
\hline \multicolumn{1}{c}{ Variabel Bebas } & B & Beta & T & Prob. \\
\hline Corporate Image $(\mathrm{X})$ & 0,991 & 0,762 & 14,328 & 0,000 \\
& & & & \\
\hline Variabel Terikat & Kepercayaan $\left(\mathrm{Y}_{1}\right)$ & & & \\
F Fitung & 205,300 & & & \\
Probabilitas & 0,000 & &
\end{tabular}

Sumber: data diolah peneliti, 2016

Berdasarkan tabel 2, maka persamaan jalur hubungan kausal antara corporate image (X) terhadap kepercayaan $\left(\mathrm{Y}_{1}\right)$ sebagai berikut:

$\mathrm{Y}_{1}=0,762 \mathrm{X}$
Hasil Uji t untuk menguji pengaruh brand equity terhadap kepercayaan diperoleh nilai $t_{\text {hitung }}=$ 14,328 dengan nilai $0,000<0,05$ maka dinyatakan hubungan kausal antara corporate image dengan kepercayaan signifikan.

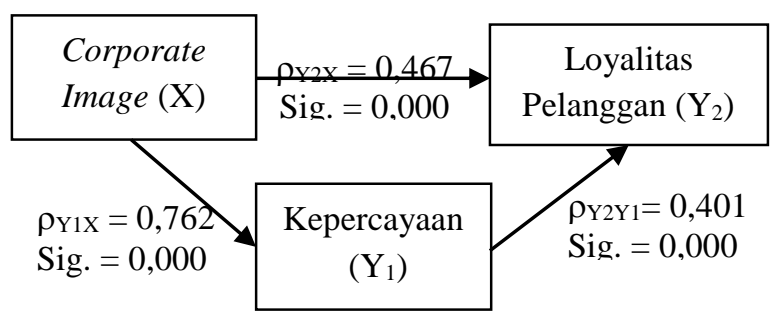

Gambar 2. Hasil Analisis Jalur 
Berdasarkan dekomposisi statistik yang peroleh sebagaimana disajikan pada gambar di atas, ternyata masing-masing jalur signifikan, sehingga model dekomposisi empirik yang diperoleh sama dengan dekomposisi statistik tersebut.

Adapun persamaan jalur yang diperoleh dari model dekomposisi statistik tersebut adalah sebagai berikut:

a. Pengaruh corporate image $(\mathrm{X})$ dan kepercayaan $\left(\mathrm{Y}_{1}\right)$ terhadap loyalitas pelanggan $\left(\mathrm{Y}_{2}\right)$

$$
Y_{2}=0,467 X+0,401 Y_{1}
$$

b. Pengaruh corporate image $(\mathrm{X})$ terhadap kepercayaan $\left(\mathrm{Y}_{1}\right)$

$$
\mathrm{Y}_{1}=0,762 \mathrm{X}
$$

Selanjutnya untuk membandingkan pengaruh langsung dan tidak langsung dari jalur yang ada dengan cara mengalikan koefisien jalur pada masing-masing jalur yang terbentuk, nilai perkalian yang paling tinggi merupakan jalur terbaik yang dapat digunakan, adapun besarnya pengaruh langsung dan tidak langsung dapat dihitung sebagai berikut:

1) Pengaruh langsung corporate image $(\mathrm{X})$ terhadap loyalitas pelanggan $\left(\mathrm{Y}_{2}\right)$ dengan koefisien jalur $\rho$ Y2X $=0,467$

2) Pengaruh tidak langsung corporate image (X) terhadap loyalitas pelanggan $\left(\mathrm{Y}_{2}\right)$ melalui kepuasan konsumen $\left(\mathrm{Y}_{1}\right)$ dengan koefisien jalur $\rho_{\mathrm{Y} 1 \mathrm{X}} \times \rho_{\mathrm{Y} 1 \mathrm{Y} 2}=0,762 \times 0,401$ $=0,306$

Tabel 3.

Pengaruh Langsung dan Tidak Langsung

\begin{tabular}{cccc}
\hline \multirow{2}{*}{ Variabel } & \multicolumn{2}{c}{ Pengaruh Langsung } & Pengaruh Tidak \\
& Y1 & Y2 & Langsung \\
\hline X & 0,762 & 0,467 & 0,306 \\
Y1 & & 0,401 & \\
\hline
\end{tabular}

Sumber: Data diolah.

Berdasarkan uji pengaruh langsung dan tidak langsung pada tabel di atas dapat diketahui bahwa corporate image berpengaruh (X) langsung terhadap loyalitas pelanggan (Y2) dengan koefisien beta 0,467. Sedangkan pengaruh tidak langsung corporate image (X) terhadap loyalitas pelanggan (Y2) melalui kepercayaan (Y1) adalah sebesar 0,306. Dengan demikian corporate image memiliki pengaruh langsung yang lebih besar terhadap loyalitas pelanggan dibandingkan pengaruh tidak langsung yaitu melalui pembentukan kepercayaan pelanggan.

\section{KESIMPULAN}

Loyalitas pelanggan mobil LCGC (low MPV) Toyota disebabkan karena citra perusahaan Toyota yang dinilai baik oleh pelanggan. Jadi citra Toyota menjadi keunggulan Toyota dalam membentuk loyalitas pelanggan dan menjadi kunci keberhasilan Toyota dalam memasarkan mobil LCGC Toyota.
Citra perusahaan mampu membangun kepercayaan pelanggan mobil LCGC (low MPV) Toyota. Jadi Jadi citra Toyota menjadi keunggulan Toyota karena mampu menciptakan kepercayaan pelanggan dan menjadi kunci keberhasilan Toyota dalam memasarkan mobil LCGC Toyota, karena pelanggan memiliki kepercayaan terhadap produk Toyota.

Kepercayaan pelanggan terhadap Toyota mampu menciptakan loyalitas pelanggan, jadi kepercayaan menjadi mediasi peranan citra perusahaan terhadap loyalitas pelanggan.

Penelitian ini hanya fokus pada mobil LCGC (Low MPV) Toyota, disarankan kepada peneliti berikutnya mengembangkan atau membandingkan dengan mobil LCGC merek lain seperti yang dipasarkan oleh Daihatsu, Honda, Suzuki, dan Datsun.

Penelitian ini tidak mempertimbangkan dimensi- dimensi dari produk mobil LCGC Toyota, sebagai mobil murah ramah lingkungan, sehingga perlu dikembangkan penelitian khususnya aspek harga dan produk mobil LCGC sehingga diperoleh temuan mengapa mobil LCGC bisa diterima pasar Indonesia. 


\section{DAFTAR PUSTAKA}

Chodzaza, Gilbert E \& Gombachika, Harry SH., Service Quality, 2013, Customer Satisfaction and Loyalty among Industrial Customers of a Public Electricity Utility on Malawi, International Journal of Energy Sector Management, Emerald Group Publishing, Vol. 7 No. 2, 269-282.

Dornas, Karen Beatriz, Jose Marcos Carvalho de Mesquita, and Rachel Patrocinio, 2014, The Relationship Between Trust, Value and Loyalty in the Internet Era, Journal of Business and Economics, Vol. 5 No. $5,802-812$.

Duffy, Deniss L., 2003. Internal and External Factors Which Affect Cuustomer Loyalty, Journal of Consumer Marketing, Emerald Group Publishing, Vol. 20, No. 5, 480-485.

Kassim, Norizan \& Abdullah, Noor Asiah. 2010, The Effect of Perceived Service Quality Dimensions on Customer Satisfaction, Trust, and Loyalty in e-commerce Setting, Asia Pacific Journal of Marketing and Logistics, Emerald Group Publishing, Vol. 22 No. 3, 351371

Kim, W.G. \& Ryu, K., Lee, H.R., 2012. The Influence of the Quality of The Physical Environment, Food, and Service on Restaurant Image, Customer Perceived Value, Customer Satisfaction, and
Behavioral Intentions. International Journal of Contemporary Hospitality Management, Vol. 24 No. 2, 200-223.

Lin, Long-Yi \& Ching-Yuh Lu, 2010, The Influence of Corporate Image, Relationship Marketing, and Trust on Purchase Intention: The Moderating Effects of Word-of-mouth, Tourism Review, Emerald Group Publishing. Vol. 65 Iss 3 pp. 16 - 34

Kotler, P., D. H. Haider and I. Rein, 1993. Marketing Places, The Free Press, New York.

Kotler, P 2000. Marketing Management Millenium, Upper Sadle River, New Jersey: A Person Education Company

Rowley, Jeniffer. 2005, The Four Cs of Customer Loyalty, Marketing Inteligence \& Planning, Emerelad Vol. 23, No. 6. 574-581.

Saputra, R, Herdi M, 2015.Perang Mobil Jepang di Indonesia Kian Sengit, available at: http://fokus.news.viva.co.id/news/read/ 574252-2015-perang-mobil-jepang-diindonesia-kian-sengit

Sheth \& Mittal, 2004, Customer Behavior: A Managerial Perspective, South-Western Publication.

Tjiptono, Fandy. 2006, Pemasaran Jasa, Cetakan Kedua, Penerbit Bayumedia Publishing, Malang 